\title{
Comment on "A preserved early Ediacaran magmatic arc at the northernmost part of the transversal zone - central domain of the Borborema Province, Northeast of South America”, by B. B. de Brito Neves et al. (2016)
}

\author{
Sérgio Pacheco Neves ${ }^{1 *}$ (i)
}

\begin{abstract}
The recent proposition for a long-lived (635-580 Ma) magmatic arc in the central portion of the Borborema Province is critically evaluated. Evidence favoring subduction include: low-T, high-P metamorphism; local occurrence of retroeclogites; and the probable participation of juvenile material in the genesis of 630-620 Ma-old plutons. However, several factors argue against the existence of a large ocean separating the Northern and Central subprovinces. First, early Tonian detrital zircons (1.0-0.9 Ga) in the Northern Subprovince indicate derivation from the Central Subprovince, and thus a connection between them until the time of deposition ( ca. $660 \mathrm{Ma}$ ). Second, the age of peak metamorphism in the Northern Subprovince implies concomitant deformation in the upper and lower plates at 630-610 Ma. Third, 630-620 Ma-old granites have characteristics (e.g., high $\delta O^{18}$ values, low magnetic susceptibility) unlike plutons emplaced in continental active margins. Fourth, 590-580 Ma-old granites are clearly syn-transcurrent, i.e., post-collisional. Finally, the Patos shear zone, proposed to be a boundary transform between the two plates, is younger than $570 \mathrm{Ma}$, and thus cannot represent a suture zone. Therefore, if a magmatic arc existed, it had short duration and was developed at the end of the Cryogenian.
\end{abstract}

KEYWORDS: subduction; collision; detrital zircons; granitic magmatism; orogenic metamorphism.

\section{INTRODUCTION}

The accretionary model for the Neoproterozoic evolution of the Borborema Province vindicates that it would be the product of collage of several distinct terranes (Santos and Medeiros 1999, Brito Neves et al. 2000, Padilha et al. 2017). In this model, subduction zones would be present not only around the periphery of the Borborema Province but also in its interior. Whereas a subduction to collision setting is well-established in the Central Ceará Domain, as indicated, for instance, by juvenile magmatic rocks with arc characteristics in the Tamboril-Santa Quitéria Complex and by the occurrence of high- to ultra-high P metabasic rocks (e.g., Araújo et al. 2014, Santos et al. 2015), the former existence of several subduction zones in the interior of the Borborema Province is disputed
(Neves 2003, 2015). It is in the context of the accretionary model that Brito Neves et al. (2016) recently proposed a magmatic arc, lasting from 635 to $580 \mathrm{Ma}$, in the Piancó-Alto Brígida belt (western portion of the Central Subprovince of the Borborema Province). Additionally, they and Brito Neves and Campos Neto (2016) proposed that the Patos shear zone is a continental plate boundary transform separating lithologies of the lower (the Northern Subprovince) and upper (the Central Subprovince) plates, and attributed low-grade metasedimentary rocks between the inferred arc and the Patos shear zone to deformation of sediments deposited in a forearc basin. Here, I critically review the available information derived from geological, geochemical, isotopic and geochronological data pertaining to the geological evolution of the Piancó-Alto Brígida belt, and discuss:

${ }^{1}$ Departamento de Geologia, Universidade Federal de Pernambuco - Recife (PE), Brazil. E-mail: serpane@hotlink.com.br

Manuscript ID: 20180049. Received on: 01/24/2018. Approved on: 07/07/2018. 
whether a subduction zone existed in this area;

if it was the case, how long it lasted;

the tectonic significance of the Patos shear zone.

\section{GEOLOGICAL SETTING}

The Piancó-Alto Brígida belt (equivalent to the Cachoeirinha-Salgueiro belt; Sial 1986, Sial and Ferreira 2016) consists of low-grade metapelites and metagraywacks of the Cachoeirinha Group and higher grade micaschists of the Salgueiro Group (Kozuch 2003, Medeiros 2004). $\mathrm{U}-\mathrm{Pb}$ dating of metavolcanic rocks and of detrital zircons in metasedimentary rocks of the Cachoeirinha Group indicate that deposition occurred in the Late Neoproterozoic (<650 Ma), possibly with the top of the sequence being synorogenic (Kozuch 2003, Medeiros 2004, Van Schmus et al. 2011). The Piancó-Alto Brígida belt is intruded by a large number of plutons and batholiths, the most abundant represented by two groups of granitoids (Sial 1986, Sial and Ferreira 1990, Mariano and Sial 1990, Mariano et al. 1996, Ferreira et al. 1998, Sial and Ferreira 2016):

- epidote-bearing, equigranular, calc-alkaline tonalites to granodiorites, regionally known as Conceição type;

- high-K calc-alkaline porphyritic granites to quartz monzonites associated with enclaves and dike swarms of K-rich biotite diorites to quartz diorites, regionally known as Itaporanga type.

The first group comprises c. 50 plutons and the second one is represented by three large batholiths. There are very few geochronological data available for these rocks. Brito Neves et al. (2003) reports a U-Pb TIMS age of $635 \pm 9 \mathrm{Ma}$ for the Conceição pluton (type locality of group 1), but with a large mean standard weighted deviation (MSWD) (22). Given the low grade of the country rocks, it is possible that the ${ }^{40} \mathrm{Ar} /{ }^{39} \mathrm{Ar}$ age of $618 \pm 2.7 \mathrm{Ma}$ obtained in amphibole (Sial and Ferreira 1990) more closely approaches the age of crystallization. For the Itaporanga batholith, a better constrained $\mathrm{U}-\mathrm{Pb}$ age of $584 \pm 2 \mathrm{Ma}$ is available $(M S W D=2.5)$ (Brito Neves et al. 2003). In spite of the limited number of data, it is clear that intrusion of group 1 granitoids is older, probably occurring in the interval 635-615 Ma, whereas intrusion of group 2 granitoids took place at ca. 590-580 Ma.

\section{EVIDENCE FOR SUBDUCTION}

Previous models had already suggested the genesis of group 1 granitoids in relation to subduction (Medeiros
2004; Caby et al. 2009; Sial and Ferreira 2016). The main difference with the model of Brito Neves et al. (2016) is that these latter authors propose a long-lived magmatic arc still active during intrusion of group 2 granitoids, thus implying over $50 \mathrm{Ma}$ of arc magmatism. This proposition requires the existence of a large oceanic domain between the Northern and Central subprovinces. Lines of evidence supporting the former existence of a subduction zone in the Piancó-Alto Brígida belt include:

- lenses of metamafic and metaultramafic rocks that occur near Bodocó town, in the western portion of the domain, that record peak metamorphic conditions of the order of $13 \mathrm{kbar}$ and $525^{\circ} \mathrm{C}$, symptomatic of subduction metamorphism (Beurlen et al. 1992);

- thermobarometric estimates for metapelites indicating pressure $(\mathrm{P})$-temperature $(\mathrm{T})$ conditions for the regional metamorphism of 6-7 kbar and $420 \pm 20^{\circ} \mathrm{C}$, implying a high $\mathrm{P} / \mathrm{T}$ geothermal gradient, also consistent with subduction (Caby et al. 2009);

whole-rock chemical analyzes of Group 1 granitoids falling on the field of arc granites in tectonic discrimination diagrams (Ferreira et al. 2004; Fig. 1A);

(d) Late Mesoproterozoic (1.2-1.3 Ga) Nd-model ages and slightly negative $\mathrm{e}_{\mathrm{Nd}}(600 \mathrm{Ma})$ values $(-1.2-2.0)$ (Brito Neves et al. 2003; Sial and Ferreira 2016) of the Conceição-type plutons, suggesting interaction of juvenile calc-alkaline magmas with older crustal material, a common situation in continental magmatic arcs.

Therefore, metamorphism of the sedimentary package and conversion of mafic rocks to eclogite were attributed to the transport of these lithologies to depths up to $45 \mathrm{~km}$ in a subduction channel, shortly followed by intrusion of calc-alkaline magmas (Caby et al. 2009). Sial and Ferreira (2016) estimated the interval 650-620 Ma for the closure of a narrow oceanic basin by activities along a subduction zone dipping southeastward.

\section{EVIDENCE AGAINST A LONG-LIVED MAGMATIC ARC}

Although the Conceição-type plutons have some characteristics suggestive of magma generation associated with subduction, several geological aspects are unlike those of calc-alkaline batholiths found on active continental margins:

- I-type granitoids in this setting are part of the calc-alkaline suite, which includes important volumes of mafic and intermediate rocks (gabbros and diorites), which contrasts with their restricted occurrence in the Conceição-type 
plutons. This is reflected in the small compositional range of silica contents (62-72 wt.\%; Ferreira et al. 2004) as compared with that typical of calc-alkaline magmas (50-80 wt.\% $\mathrm{SiO}_{2}$; e.g., Stern 2002);

- Calc-alkaline plutons belong to the magnetite-type series (Ishihara 1977) whereas the Conceição-type plutons have low magnetic susceptibilities (Sial and Ferreira 2016);

- The whole-rock high $\delta \mathrm{O}^{18}$ values $(10-13 \%$ ) of the Conceição-type granites (Sial 1993, Sial and Ferreira 2016) are distinct from those of arc granites, which typically have less than 8\%o (O'Neil et al. 1977);

- Amphibolite xenoliths, interpreted as fragments of metabasaltic source rocks, also exhibit high values of $\delta \mathrm{O}^{18}$ (Sial and Ferreira 2016), which contrasts with the mantle values of c. $5 \%$ typical of unaltered oceanic crust (e.g., Valley et al. 2005);

- If partial melting of amphibolite in the oceanic part of the slab had occurred during subduction, adakitic melts would be produced (e.g., Defant and Kepezhinskas 2001), which have geochemical characteristics (e.g., high Sr/Y) rather distinct from those of the Conceição-type granites.

If the origin of the Conceição-type plutons in a magmatic arc is questionable, still more is the case of the Itaporanga-type granites. There is no evidence for subduction zone processes at the time of their emplacement at 590-580 Ma and they are clearly syn-transcurrent (Archanjo et al. 1999). Although strike-slip shear zones occur at convergent margins, they are much more commonly developed following crustal thickening in a collisional setting. Therefore, associated plutons are commonly dubbed post-collisional. These plutons have dominantly high-K calc-alkaline signature (e.g., Liégeois et al. 1998),

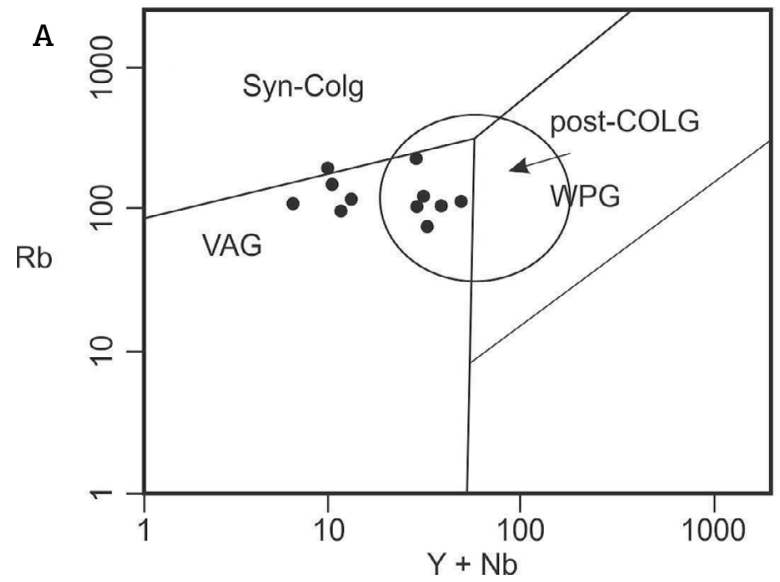

which is the case of group 2 granitoids (McMurry et al. 1987, Mariano et al. 1996). Unsurprisingly, most analyses of the Itaporanga-type plutons plot in the post-collisional field in tectonic discrimination diagrams (Fig. $1 \mathrm{~B})$. Furthermore, they have negative $\mathrm{e}_{\mathrm{Nd}}$ values and Paleoproterozoic Nd model ages (Mariano et al. 2001, Brito Neves et al. 2003, Sial and Ferreira 2016), indicating derivation from ancient continental lithosphere, with little or no involvement of juvenile material in their genesis, rather unlike arc-related granitoids.

Brito Neves et al. (2016) enumerate a series of compositional, structural and geochronological differences between the Northern Subprovince and the Central Subprovince (their Tab. 3). However, they do not elaborate the argument for subduction of the first (the lower plate) under the latter (the upper plate). There are two critical constraints that must be considered in this respect that were not dealt with in the Brito Neves et al. (2016) paper. The first is provided by the ages of detrital zircons in the supracrustal sequences of the lower plate. Several samples of metasedimentary rocks in the Ceará Complex of the Central Ceará Domain (Araújo et al. 2012, Kalsbeek et al. 2013, Garcia et al. 2014, Ancelmi et al. 2015, Arthaud et al. 2015) and in the Seridó Group of the Rio Grande do Norte Domain (Van Schmus et al. 2003, Kalsbeek et al. 2013, Hollanda et al. 2015) contain a significant number of zircons in the age range 1000-920 Ma (Fig. 2). Rocks of these ages are unknown in the North Subprovince, where the oldest Neoproterozoic record of magmatic activity is represented by an orthogneiss from the Lagoa Caiçara unit that yielded an age of $833 \pm 6 \mathrm{Ma}$ (Araújo et al. 2014). Hence, the most likely derivation of these detrital early Tonian zircons is from sources related to the Cariris Velhos event in

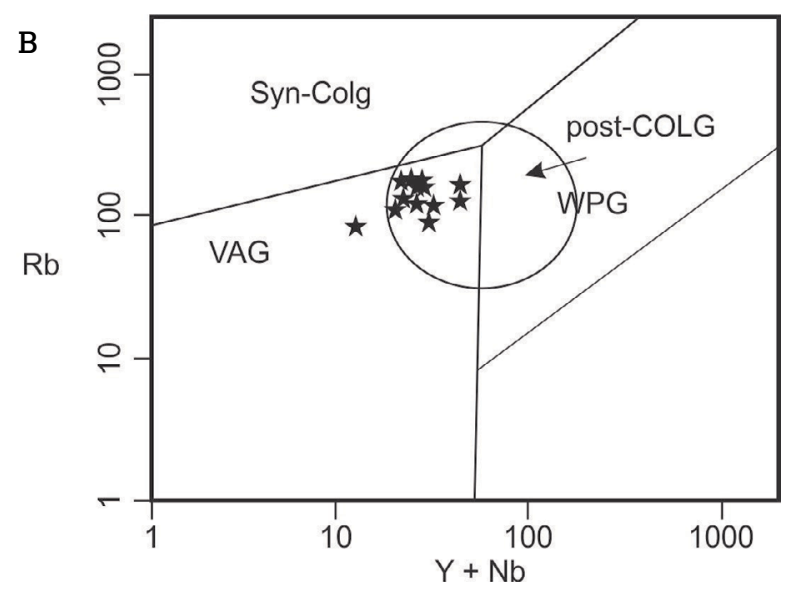

Syn-Colg: syn-collisional granite; VAG: volcanic arc granite; WPG: within-plate granite.

Figure 1. Tectonic discrimination diagrams (Pearce et al. 1984) for granitoids in the Piancó-Alto Brígida belt. (A) Epidote-bearing calc-alkaline plutons. (B) High-K calc-alkaline plutons. Modified from Ferreira et al. (2004), with addition of the post-collisional field (post-COLG) of Pearce (1996). 
the Central and Southern subprovinces (Santos et al. 2010, Guimarães et al. 2016), implying a connection between the Northern and Central subprovinces at the time of deposition. The maximum time of deposition constrained by the ages of the youngest detrital zircon populations are ca. $660 \mathrm{Ma}$ and $630 \mathrm{Ma}$, respectively, in the Ceará Complex and Seridó Group (Fig. 2).

The second constraint is the age of regional deformation and metamorphism in the Northern Subprovince. Whereas these processes appear to have been initiated only after ca. $600 \mathrm{Ma}$ in the Rio Grande do Norte Domain (Souza et al. 2006, Archanjo et al. 2013), the ages of metamorphic zircons in the Ceará Complex imply that they already had started 640-630 Ma ago (Araújo et al. 2012, Garcia et al. 2014). A pool of 20 analyses of metamorphic zircons from the Ceará Complex gives an age peak of $622 \mathrm{Ma}$ (Fig. 2), which overlaps with the age of the Conceição pluton. As deformation of the lower plate cannot occur in the pre-collisional phase, concomitant deformation in the upper and lower plates implies that collisional processes were already occurring at ca. $630 \mathrm{Ma}$. Therefore, it appears that at most a few tens of millions of years are available for formation and consumption of oceanic lithosphere between the Piancó-Alto Brígida and Central Ceará domains, and that an oceanic stage was probably never reached in the Rio Grande do Norte Domain.

Brito Neves and Campos Neves (2016) and Brito Neves et al. (2016) interpret the Patos shear zone as a boundary transform, implying that its development started very early during the geological evolution of the region. This shear zone is one of the most expressive in the Borborema Province (Corsini et al. 1991, Vauchez et al. 1995), which makes it a potential candidate for a suture zone. However, recent studies show that the Patos shear zone is a late intracontinental shear zone, with no evidence that it reworked a previous transform contact (Archanjo et al. 2008; Viegas et al. 2013, 2014). Recrystallized rims in zircon crystals recovered from leucosomes of melt-bearing mylonites and crystallization ages of syn-kinematic plutons indicate the age interval 566-558 Ma for the high-grade metamorphism (Viegas et al. 2013, 2014). This age range is ca. $20 \mathrm{Ma}$ younger than the age of other high-temperature shear zones in the Borborema Province (Neves et al. 2004, 2006, Archanjo et al. 2008), showing that the Patos shear zone was the
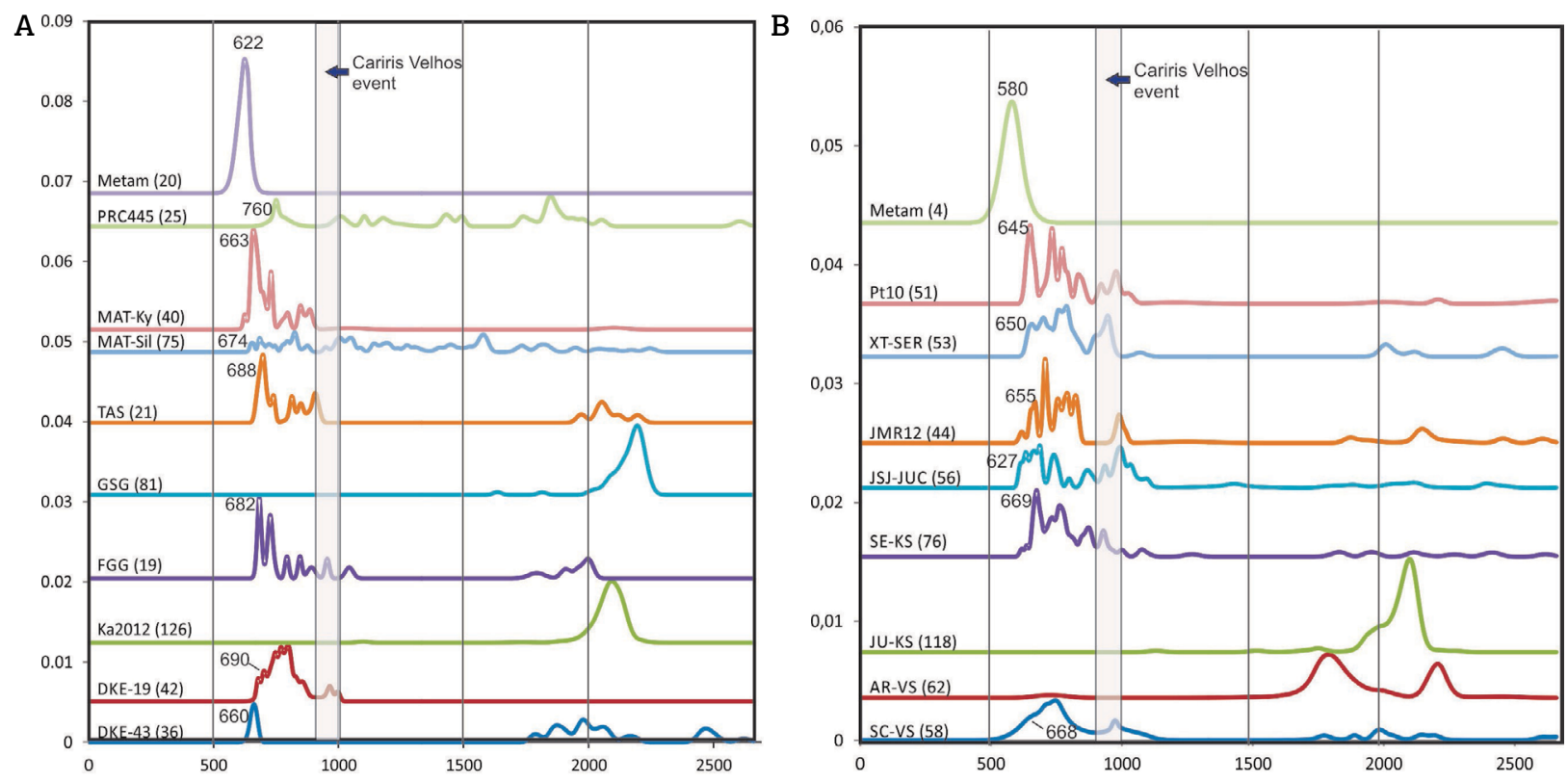

FGG: felsic garnet gneiss; GSG: garnet sillimanite gneiss; TAS: tremolite-actinolite schist.

Figure 2. Stacked relative age probability curves comparing ages of detrital zircon grains from samples of the Central Ceará Complex (A) and Seridó Group (B). Number of analyses is shown in parenthesis after sample labels. Also shown are the ages of the youngest zircon populations and the age interval corresponding to the Cariris Velhos event. The uppermost curve (Metam) in the diagrams is a pool of metamorphic ages in several samples. Sources of data: SC-VS and AR-VS, Van Schmus et al. (2003) (SC and AR stand for micaschist and metarkosic samples, respectively); Ka2012, JU-KS and SE-KS, Kalsbeek et al. (2013) (JU and SE stand for the Jucurutu and Seridó Formations); DKE-19 and DKE-43, Araújo et al. (2012); FGG, GSG and TAS, Garcia et al. (2014); MAT-Sil and MAT-Ky, Ancelmi et al. (2015) (Sil and Ky stand for sillimanite- and kyanite-bearing samples, respectively); PRC445, Arthaud et al. (2015); JSJ-JUC, JMR12, XT-SER and PT10, Hollanda et al. (2015). 
last of the major strike-slip shear zones developed during the Brasiliano Orogeny.

Brito Neves and Campos Neto (2016) attributed the rather low-grade rocks of the Rio Salgado belt (their Fig. 2), which is located between the inferred arc and the Patos shear zone, to deformation of sediments deposited in a forearc basin. However, these rocks contain a large fraction of detrital zircons with ages similar to the age of the Conceição pluton (Fig. 9 of Brito Neves and Campos Neto 2016). Therefore, deposition probably occurred in an intermontane basin coeval with deposition of the upper unit of the Cachoeirinha Group, which is not intruded by the Conceição-type plutons (Medeiros 2004) and exhibits petrographic, deformational and metamorphic characteristics similar to the Rio Salgado belt rocks. Furthermore, recent structural and geochronological results show that by 605-590 Ma extensional processes predominated in the Piancó-Alto Brígida Domain (Archanjo 2015), probably reflecting increased thickness and crustal elevation that allowed the vertical stress to overcome the horizontal tectonic stress, inducing orogenic collapse. This event was followed in a short time span, or partially overlapped with, nucleation and growth of transcurrent shear zones, a common situation in collisional and intracontinental orogens (Raimondo et al. 2010, 2014, Faure et al. 2012).

\section{FINAL REMARKS}

A connection between the subprovinces that comprise the Borborema Province before the Brasiliano Orogeny was first proposed by Neves (2003). The main arguments are reviewed by Neves (2015) and are supported by other studies. In the words of Arthaud et al. (2015):

Zircon populations recorded in the Ceará Group characterize also the Seridó Group in Rio Grande do Norte (Van Schmus et al, 2003) and the East Pernambuco in the Transversal Zone domain (Neves et al., 2006). It appears that these three metasedimentary sequences, presently separated by large ductile strike-slip shear zones, experienced the same evolution and probably belonged to the same continental mass since the Paleoproterozoic.

This interpretation was questioned by Brito Neves et al. (2016), which stated that:

According to these researchers, the Borborema Province has behaved as an intracratonic setting since the late Paleoproterozoic. This means that all fold belts and granitic plutonism were the product of lithosphere extension without any formation of oceanic crust, followed by compression due to far-field stresses.

The statements in the last sentence are incorrect. First, Neves and co-workers never attributed the genesis of granitic plutons younger than $630 \mathrm{Ma}$ to extension. Instead, they were always considered to be syn-orogenic (e.g., Neves et al. 2000, 2006, 2012). Second, the proposition of dominantly intracontinental deformation during the Brasiliano Orogeny does not preclude the local occurrence of subduction, as clearly stated by Neves (2003):

As a result, far-field tensional stresses transmitted to the interior of Atlantica may have promoted extension and development of continental rift basins (Figure 8a). Some of these basins evolved to a proto-oceanic stage, with subsequent subduction and oceanic closure leading to the local occurrence of eclogites in the central domain of the Borborema province [Beurlen et al., 1992].

And

Subduction of oceanic lithosphere explains the low-temperature and medium- to high-pressure metamorphism in the Cachoeirinha belt, which stands in contrast with the general high-temperature metamorphism of other sectors of the Borborema province.

The results reviewed above support the occurrence of a short-lived Wilson Cycle in the Central Subprovince and are fully consistent with previous works. What they contradict are the conclusions by Brito Neves et al. (2016) that the Central and Northern subprovinces belonged to separate plates, that a magmatic arc with a lifespan of $55 \mathrm{Ma}$ existed in the Central Subprovince, and that the Patos shear zone is a boundary transform. The available data favor extension of a single continental block shortly before the Brasiliano Orogeny. At most, a few tens of millions of years would separate the formation of oceanic lithosphere and its complete consumption in a hypothetical subduction zone. The time interval for the sequence of events rift $\rightarrow$ drift $\rightarrow$ convergence $\rightarrow$ initial collision is of the order of $20 \mathrm{Ma}$, approximately between 650 and $630 \mathrm{Ma}$. In this short time span, it is unlikely that the newly formed oceanic lithosphere had reached dimensions large enough to be subducted to depths below $80-100 \mathrm{~km}$, which are required to promote the onset of 
arc magmatism (e.g., Ernst 1999, Stern 2002, Tatsumi 2005). Therefore, if a magmatic arc existed, it is late Cryogenian, not early Ediacaran. However, it is more likely that calc-alkaline plutons in the Piancó-Alto Brígida Domain record syn-collisional magmatism, the dimension of the newly formed oceanic lithosphere being too small to reach the required depth during subduction to promote partial melting of the mantle wedge or of the oceanic portion of the slab.

In synthesis, there is supporting evidence for subduction in the Piancó-Alto Brígida belt, but existence of a magmatic arc is open to discussion, and if one arc existed, it was of short duration.

\section{ACKNOWLEDGMENTS}

Financial support from grants of $\mathrm{CNPq}(472582 / 2011-9$ and 449447/2014-6) and comments by Carlos Ganade de Araújo and an anonymous reviewer are acknowledged. I also thanks Carlos Archanjo for stimulating me to submit this contribution.

\section{REFERENCES}

Ancelmi M.F., Santos T.J.S., Amaral W.S., Fuck R.A., Dantas E.L., Zincone S.A. 2015. Provenance of metasedimentary rocks from the Cear_a Central Domain of Borborema Province, NE Brazil: implications for the significance of associated retrograded eclogites. Journal of South American Earth Sciences, 58:82-99. http://dx.doi. org/10.1016/j.jsames.2014.12.007

Araújo C.E.G., Cordani U.G., Basei M.A.S., Castro N.A., Sato K., Sproesser W.M. 2012. U-Pb detrital zircon provenance of metasedimentary rocks from the Ceará Central and MédioCoreaú Domains, Borborema Province, NE-Brazil: Tectonic implications for a long-lived Neoproterozoic active continental margin. Precambrian Research, 206-207:36-51. http://dx.doi.org/10.1016/j. precamres.2012.02.021

Araújo C.E.G., Cordani U.G., Weinberg R.F., Basei M.A.S., Armstrong R., Sato K. 2014. Tracing Neoproterozoic subduction in the Borborema Province (NE-Brazil): Clues from U-Pb geochronology and Sr-NdHf-O isotopes on granitoids and migmatites. Lithos, 202-203:167189. http://dx.doi.org/10.1016/j.lithos.2014.05.015

Archanjo C.J. 2015. Geocronologia, estruturas de alojamento e deformação do batólito Salgueiro (Faixa Cahoeirinha, PE). In: Simpósio de Geologia do Nordeste, 26. Atas..., p. 157.

Archanjo C.J., da Silva E.R., Caby R. 1999. Magnetic fabric and pluton emplacement in a transpressive shear zone system: the Itaporanga porphyritic granitic pluton (northeast Brazil). Tectonophysics, 312:331-345. https://doi.org/10.1016/S0040-1951(99)00176-6

Archanjo C.J., Hollanda M.H.B.M., Rodrigues S.W.O., Brito Neves B.B., Armstrong R. 2008. Fabrics of pre- and syntectonic granite plutons and chronology of shear zones in the Eastern Borborema Province, NE Brazil. Journal of Structural Geology, 30:310-326. http://dx.doi. org/10.1016/j.jsg.2007.11.011

Archanjo C.J., Viegas L.G.F., Hollanda M.H.B.M., Souza L.C., Liu D. 2013. Timing of the HT/LP transpression in the Neoproterozoic Seridó Belt (Borborema Province, Brazil): Constraints from U\Pb (SHRIMP) geochronology and implications for the connections between NE Brazil and West Africa. Gondwana Research, 23:701714. http://dx.doi.org/10.1016/j.gr.2012.05.005

Arthaud M.H., Fuck R.A., Dantas E.L, Santos T.J.S., Caby R., Armstrong R. 2015. The Neoproterozoic Ceará Group, Central Ceará domain, NE Brazil: depositional age and provenance of detrital material. New insights from U-Pb and Sm-Nd geochronology. Journal of South American Earth Sciences, 58:223-237. http://dx.doi.org/10.1016/j.jsames.2014.09.007

Beurlen H., Silva Filho A.F., Guimarães I.P., Brito, S.B. 1992. Proterozoic C-type eclogites hosting unusual $\mathrm{Ti}$ - $\mathrm{Fe} \pm \mathrm{Cr} \pm \mathrm{Cu}$ mineralization in northeastern Brazil. Precambrian Research, 58:195-214. https://doi. org/10.1016/0301-9268(92)90119-9
Brito Neves B.B., Campos Neto M.C. 2016. A faixa de dobramentos do Rio Salgado, norte-noroeste da Zona Transversal-Província Borborema (PB-CE). Geologia USP, Série Científica, 16:3-17. http:// dx.doi.org/10.11606/issn.2316-9095.v16i3p3-17

Brito Neves B.B., Santos E.J., Van Schmus W.R. 2000. Tectonic history of the Borborema province. In: Cordani U.G., Milani E.J., Thomaz Filho A., Campos D.A. (Eds.). Tectonic evolution of South America. $31^{\circ}$ International Geological Congress, Rio de Janeiro, 151-182.

Brito Neves B.B., Passarelli C.R., Basei M.A.S., Santos E.J. 2003. Idades U-Pb de alguns granitos clássicos da Província Borborema. Geologia USP, Série Científica, 3:25-28. http://dx.doi.org/10.5327/ S1519-874X2003000100003

Brito Neves B.B., Santos E.J., Fuck R.A., Santos L.C.M.L. 2016. A preserved early Ediacaran magmatic arc at the northernmost portion of the Transversal Zone central subprovince of the Borborema Province, Northeastern South America. Brazilian Journal of Geology, 46:491-508. http://dx.doi. org/10.1590/2317-4889201620160004

Caby R., Sial A.N., Ferreira V.P. 2009. High-pressure thermal aureoles around two Neoproterozoic synorogenic magmatic epidote-bearing granitoids, northeastern Brazil. Journal of South American Earth Sciences, 27:184-195. http://dx.doi.org/10.1016/j. jsames.2008.09.005

Corsini M., Vauchez A., Archanjo C.J., Jardim de Sá E.F. 1991. Strain transfer at a continental scale from a transcurrent shear zone to a transpressional fold belt: the Patos-Serido belt system (northeastern Brazil). Geology, 19:586-589. https://doi. org/10.1130/0091-7613(1991)019\%3C0586:STACSF\%3E2.3.CO;2

Defant M.J., Kepezhinskas P. 2001. Adakites: a review of slab melting over the past decade and the case for a slab-melt component in arcs. Eos, 82:65-69.

Ernst W.G. 1999. Hornblende, the continent maker - Evolution of $\mathrm{H}_{2} \mathrm{O}$ duringcircum-Pacificsubductionversus continental collision.Geology, 27:675-678. https://doi.org/10.1130/0091-7613(1999)027\%3C067 5:HTCMEO\%3E2.3.CO;2

Faure M., Lin W., Chen Y. 2012. Is the Jurassic (Yanshanian) intraplate tectonics of North China due to westward indentation of the North China block? Terra Nova, 24:456-466. https://doi.org/10.1111/ ter.12002

Ferreira V.P., Sial A.N., Jardim de Sá E.F. 1998. Geochemical and isotopic signatures of Proterozoic granitoids in terranes of the Borborema structural province, northeastern Brazil. Journal of South American Earth Sciences, 11:439-455. http://dx.doi.org/10.1016/ S0895-9811(98)00027-3 
Ferreira V.P., Sial A.N., Pimentel M.M., Moura C.A.V.2004. Intermediate to acidic magmatism and crustal evolution in the Transversal Zone, Northeastern Brazil. In: Mantesso-Neto V., Bartorelli A., Carneiro C.D.R., Brito Neves B.B. (Eds.). Geologia do Continente Sul-Americano - Evolução da Obra de Fernando Flávio Marques de Almeida. São Paulo, Beca, p. 189-201.

Garcia M.G.M., Santos T.J.S., Amaral W.S. 2014. Provenance and tectonic setting of Neoproterozoic supracrustal rocks from the Ceará Central Domain, Borborema Province (NE Brazil): constraints from geochemistry and detrital zircon ages. International Geology Review, 56:481-500. https://doi.org/10.1080/00206814.2013.875489

Guimarães I.P., Brito M.F.L., Lages G.A., Da Silva Filho A.F., Santos L., Brasilino R.G. 2016. Tonian granitic magmatism of the Borborema Province, NE Brazil: A review. Journal of South American Earth Sciences, 68:97-112. https://doi.org/10.1016/j.jsames.2015.10.009

Hollanda M.H.B.M., Archanjo C.J., Bautista J.R., Souza L.C. 2015. Detrital zircon ages and $\mathrm{Nd}$ isotope compositions of the Serido andLavras da Mangabeira basins (Borborema Province, NE Brazil): Evidence for exhumation and recycling associated with a major shift in sedimentary provenance. Precambrian Research, 258:186-207. https://doi.org/10.1016/j.precamres.2014.12.009

Ishihara S. 1977. The magnetite-series and ilmenite-series granitic rocks. Mining Geology, 27:293-305. http://dx.doi.org/10.11456/ shigenchishitsu1951.27.293

Kalsbeek F., Ekwueme B., Penaye J., Souza Z.S., Thrane K. 2013. Recognition of Early and Late Neoproterozoic supracrustal units in West Africa and North-East Brazil from detrital zircon geochronology. Precambrian Research, 226:105-115. http://dx.doi.org/10.1016/j. precamres.2012.12.006

Kozuch M. 2003. Isotopic and trace element geochemistry of early Neoproterozoic gneissic and metavolcanic rocks in the Cariris Velhos Orogen of the Borborema Province, Brazil, and their bearing on tectonic setting. PhD Thesis, University of Kansas, Kansas.

Liégeois J.-P., Navez J., Hertogen J., Black R. 1998. Contrasting origin of post-collisional high-K calc-alkaline and shoshonitic versus alkaline and peralkaline granitoids. The use of sliding normalization. Lithos, 45:1-28. https://doi.org/10.1016/ S0024-4937(98)00023-1

Mariano G., Neves S.P., Da Silva Filho A.F., Guimarães I.P. 2001 Diorites of the high-K calc-alkalic association: geochemistry and Sm-Nd data and implications for the evolution of the Borborema province, Northeast Brazil. International Geology Review, 43:921929. https://doi.org/10.1080/00206810109465056

Mariano G., Sial A.N. 1990. Coexistence and mixing of magmas in the Late Precambrian Itaporanga batholith, State of Paraíba, Northeastern Brazil. Revista Brasileira de Geociências, 20:101-110

Mariano G., Sial A.N., Cruz M.J.M., Conceição H. 1996. The Potassic Calc-Alkalic Itaporanga Batholith, Northeastern Brazil: Mineral Chemistry and Oxygen-Isotope Data. International Geology Review, 38:74-86. https://doi.org/10.1080/00206819709465325

McMurry J., Long L.E., Sial A.N. 1987. Petrology and isotope systematics of magma mushes: some porphyritic granitoids of northeastern Brazil. Revista Brasileira de Geociências, 17:473-480.

Medeiros V.C. 2004. Evolução geodinâmica e condicionamento estrutural dos terrenos Piancó-Alto Brígida e Alto Pajeú, Domínio da Zona Transversal, NE do Brasil. PhD Thesis, Universidade Federal do Rio Grande do Norte, Natal.

Neves S.P. 2003. Proterozoic history of the Borborema Province (NE Brazil): correlations with neighboring cratons and Pan-African belts, and implications for the evolution of western Gondwana. Tectonics, 22:1031. https://doi.org/10.1029/2001TC001352
Neves S.P. 2015. Constrains from zircon geochronology on the tectonic evolution of the Borborema Province: Widespread intracontinental Neoproterozoic reworking of a Paleoproterozoic accretionary orogen. Journal of South American Earth Sciences, 58:150-164. https://doi.org/10.1016/j.jsames.2014.08.004

Neves S.P., Mariano G., Correia P.B., Silva J.M.R. 2006. 70 m.y. of synorogenic plutonism in eastern Borborema Province (NE Brazil): temporal and kinematic constraints on the Brasiliano Orogeny. Geodinamica Acta, 19:213-236. https://doi.org/10.3166/ ga.19.213-236

Neves S.P., Melo S.C., Moura C.A.V., Mariano G., Silva J.M.R. 2004 Zircon $\mathrm{Pb}-\mathrm{Pb}$ geochronology of the Caruaru area, northeastern Brazil: temporal constraints on the Proterozoic evolution of Borborema Province. International Geology Review, 46:52-63. https://doi. org/10.2747/0020-6814.46.1.52

Neves S.P., Monié P., Bruguier O., Silva J.M.R. 2012. Geochronological, thermochronological and thermobarometric constraints on deformation, magmatism and thermal regimes in eastern Borborema Province (NE Brazil). Journal of South American Earth Sciences, 38:129-146. https://doi.org/10.1016/j. jsames.2012.06.003

Neves S.P., Vauchez A., Feraud G. 2000. Tectono-thermal evolution, magma emplacement, and shear zone development in the Caruaru area (Borborema Province, NE Brazil). Precambrian Research, 99:132. https://doi.org/10.1016/S0301-9268(99)00026-1

O'Neil J.R., Shaw S.E., Flood R.H. 1977. Oxygen and hydrogen isotope compositions as indicators of granite genesis in the New England Batholith, Australia. Contributions to Mineralogy and Petrology. 62:313-328. https://doi.org/10.1007/BF00371018

Padilha A.L., Vitorello I., Pádua M.B., Fuck R.A. 2017. Cryptic signatures of Neoproterozoic accretionary events in northeast Brazil imaged by magnetotellurics: Implications for the assembly of West Gondwana. Tectonophysics, 669:164-177. https://doi.org/10.1016/j. tecto.2017.01.022

Pearce J. 1996. Sources and settings of granitic rocks. Episodes, 19:120-125

Pearce J.A., Harris N.B., Tindle A.G. 1984. Trace element discrimination diagrams for the tectonic interpretation of granitic rocks. Journal of Petrology, 25:956-983. https://doi.org/10.1093/petrology/25.4.956

Raimondo T., Collins A.S., Hand M., Walker-Hallam A., Smithies R.H., Evins P.M., Howard H.M. 2010. The anatomy of a deep intracontinental orogen. Tectonics, 29:TC4024. https://doi. org/10.1029/2009TC002504

Raimondo T., Hand M., Collins W.J. 2014. Compressional intracontinental orogens: Ancient and modern perspectives. Earth-Science Reviews, 130:128-153. https://doi.org/10.1016/j. earscirev.2013.11.009

Santos E.J., Medeiros V.C. 1999. Constraints from granitic plutonism on Proterozoic crustal growth of the Transverse Zone, Borborema Province, NE Brazil. Revista Brasileira de Geociências, 29:73-84.

Santos E.J., Van Schmus W.R., Kozuch M., Brito Neves B.B. 2010 The Cariris Velhos Tectonic Event in Northeast Brazil. Journal of South American Earth Sciences, 29:61-76. https://doi.org/10.1016/j. jsames.2009.07.003

Santos T.J.S., Amaral W.S., Ancelmi M.F., Pitarello M.Z., Fuck R.A., Dantas E.L., 2015. U-Pb and Lu-Hf ages of the coesite-bearing eclogite from NW Borborema Province, NE Brazil: Implications for Western Gondwana assembly. Gondwana Research, 28:1183-1196. http://dx.doi.org/10.1016/j.gr.2014.09.013

Sial A.N. 1986. Granite types of Northeast Brazil: current knowledge. Revista Brasileira de Geociências, 16:54-72. 
Sial A.N. 1993. Contrasting metaluminous magmatic epidotebearing suites from two Precambrian fold belts in Northeast Brazil. Anais da Academia Brasileira de Ciências, 65:141-162.

Sial A.N., Ferreira V.P. 1990. Granitoids in northeastern Brazil: Oxygen and sulfur isotope compositions and depths of emplacement. Journal of South America Earth Sciences, 3(2/3):103-112. https://doi. org/10.1016/0895-9811(90)90023-T

Sial A.N., Ferreira V.P. 2016. Magma associations in Ediacaran granitoids of the Cachoeirinha-Salgueiro and Alto Pajeú terranes, northeastern Brazil: Forty yearsof studies. Journal of South American Earth Sciences, 68:113-133. https://doi.org/10.1016/j.jsames.2015.10.005

Souza Z.S., Montel J.M., Gioia S.M.L.C., Hollanda M.H.B.M., Nascimento M.A.L., Jardim de Sá E.F., Amaro V.E., Pimentel M.M., Lardeaux J.M., Veschambre M. 2006. Electron microprobe dating of monazite from high-T shear zones in the São José do Campestre Massif, NE Brazil. Gondwana Research, 9:441-455. http://dx.doi.org/10.1016/j.gr.2005.11.008

Stern R.J. 2002. Subduction zones. Reviews of Geophysics, 40. http:// dx.doi.org/10.1029/2001RG000108

Tatsumi Y. 2005. The subduction factory: How it operates in the evolving Earth. GSA Today, 15:4-10. http://dx.doi. org/10.1130/1052-5173(2005)015[4:TSFHIO]2.0.CO;2

Valley J.W., Lackey J.S., Cavosie A.J., Clechenko C.C., Spicuzza M.J., Basei M.A.S., Bindeman I.N., Ferreira V.P., Sial A.N., King E.M., Peck W.H., Sinha A.K., Wei C.S. 2005. 4.4 billion years of crustal maturation: oxygen isotope ratios of magmatic zircon. Contributions to Mineralogy and Petrology, 150:561-580. https://doi.org/10.1007/s00410-005-0025-8
Van Schmus W.R., Brito Neves B.B., Williams I.S., Hackspacher P., Fetter A.H., Dantas E.L., Babinski M. 2003. The Seridó Group of NE Brazil, a late Neoproterozoic pre- to syn-collisional basin in West Gondwana: insights from SHRIMP U-Pb detrital zircon ages and Sm-Nd crustal residence (TDM) ages. Precambrian Research, 127:287-327. http://dx.doi.org/10.1016/ S0301-9268(03)00197-9

Van Schmus W.R., Kozuch M., Brito Neves B.B. 2011. Precambrian history of the Zona Transversal of the Borborema Province, NE Brazil: Insights from Sm-Nd and U-Pb geochronology. Journal of South American Earth Sciences, 31:227-252. http://dx.doi.org/10.1016/j. jsames.2011.02.010

Vauchez A., Neves S.P., Caby R., Corsini M., Egydio-Silva M., Arthaud M.H., Amaro V. 1995. The Borborema shear zone system, NE Brazil. Journal of South American Earth Sciences, 8:247-266. https://doi. org/10.1016/0895-9811(95)00012-5

Viegas L.G.F., Archanjo C., Vauchez A. 2013. Fabrics of migmatites and the relationships between partial melting and deformation in high-grade transpressional shear zones: the Espinho Branco anatexite (Borborema Province, NE Brazil). Journal of Structural Geology, 48:45-56. https://doi.org/10.1016/j.jsg.2012.12.008

Viegas L.G.F., Archanjo C.J., Hollanda M.H.B.M., Vauchez A. 2014. Microfabrics and zircon U-Pb (SHRIMP) chronology of mylonites from the Patos shear zone (Borborema Province, NE Brazil). Precambrian Research, 243:1-17. http://dx.doi.org/10.1016/j. precamres.2013.12.020 